\title{
Performance of common bean seeds infected by the fungus Sclerotinia sclerotiorum ${ }^{1}$
}

\author{
Luana da Silva Botelho², Willian Luis Antonio Zancan²*, \\ José da Cruz Machado², Ellen Noly Barrocas²
}

\begin{abstract}
The fungus Sclerotinia sclerotiorum, causal agent of white mold disease on several economically important crops, such as bean, soybean, and cotton, is commonly disseminated through seeds and can cause high losses on their quality and in productivity of these species. The aim of this study was assessing the effects of different initial inoculums potentials of this fungus on common bean seeds using two different strains of the fungus and two genotypes of common beans (Pérola and Ouro Negro) artificially inoculated. Seeds were sown on soil and the cultivation was performed under controlled environmental conditions favorable to development of the white mold disease. Variables assessed were: germination; seed health; emergence speed index; initial and final seedling number; and dry weight of aerial parts and roots. It was found that with the gradual increase in inoculum potential in the seeds also occurred gradual reduction in the values of: germination; emergence speed index; seedling stand; and length and dry mass of aerial parts and roots. These results show the importance of initial inoculum potential of $S$. sclerotiorum present in common bean seeds, as much in disseminating the pathogen as on direct damages caused in field by reducing productive potential of the emerged plants.
\end{abstract}

Index terms: white mold, Phaseolus vulgaris, seed health.

\section{Desempenho de sementes de feijão infectadas pelo fungo Sclerotinia sclerotiorum}

\begin{abstract}
RESUMO - O fungo Sclerotinia sclerotiorum, agente etiológico da doença conhecida como mofo branco em diversas culturas de importância econômica, tais como feijão, soja e algodão, é comumente disseminado através de sementes e capaz de causar perdas elevadas na qualidade das sementes e na produtividade dessas espécies. Neste trabalho, o objetivo foi avaliar os efeitos de diferentes potenciais de inoculo inicial desse fungo nas sementes de feijão usando dois isolados do fungo e dois genótipos de feijão (Pérola e Ouro Negro) artificialmente inoculados. As sementes foram semeadas em solo e o cultivo foi conduzido em condições ambientais controladas, favoráveis ao desenvolvimento da doença mofo branco. As variáveis analisadas foram: germinação; sanidade; índice de velocidade de emergência; estande inicial e final; e massa seca da parte aérea e da raiz. Constatou-se que, com o aumento do potencial de inóculo nas sementes, houve redução gradual dos valores de germinação, índice de velocidade de emergência, estandes e comprimento e massa seca de parte aérea e raiz. Estes resultados evidenciam a importância do potencial do inóculo inicial de S. sclerotiorum associado às sementes de feijão, tanto na disseminação do patógeno quanto nos danos diretos causados no campo, reduzindo o potencial produtivo das plantas emersas.
\end{abstract}

Termos para indexação: mofo branco, Phaseolus vulgaris, sanidade de semente.

\section{Introduction}

The common bean (Phaseolus vulgaris L.) is one of main components in the food diet of many worldwide peoples, once it is rich in proteins and other nutrient that are very important in the human food. In Brazil, this leguminous is widely grown, as much by small producers, which due to their low income grow this crop in small areas, as by large producers that grow common beans in larger areas and with high technology. Nevertheless, with the increase in the cultivated area, there is an increase also in the problems related to its cultivation, chiefly by the use of low health seeds (Mertz et al., 2007).

Among main phytopathological problems, associated to common bean cultivation, the disease known as white mold,

${ }^{1}$ Submitted on $04 / 16 / 2012$. Accepted for publication on 10/08/2012.

${ }^{2}$ Universidade Federal de Lavras, Departamento de Fitopatologia, Caixa Postal 3037, 37200-000 - Lavras, MG, Brasil.

*Corresponding author < zancanwillian@gmail.com> 
caused by the fungus Sclerotinia sclerotiorum (Lib.) de Bary, is one of most destructive (Harveson et al., 2010), since the fungus infects seeds of innumerous species of cultivated plants of economical importance to Brazil, and may became a limiting factor to production of those crops. On considering the expressive contribution of common beans crop in the socioeconomic context of Brazilian agribusiness, it is possible to state that the importance of this disease is each time greater in Brazil, in relation to others producing countries. The fungus S. sclerotiorum has been frequently described as liable by the direct and indirect losses caused to common beans crop, as much on direct reduction of productivity as in reduction of quality of the grains produced. In addition, white mold disease is able to reduce sustainability of this crop in regions where the pathogen occurs with high frequency and intensity (Zancan et al., 2012).

The knowledge of association of this microorganism with the common bean seeds is of essential importance to adequate management to be used on the crop aiming at avoiding introduction as well as the fast dissemination of this pathogenic agent into free areas, once this fungus is able to affect as much the quantity as the quality of the final product. According to Machado (1988), the pathogen structures (hyphae and/or sclerotia), which may be present on the tegument or even in the internal seed structures constitute the primary inocula to epidemics development caused by this fungus. In addition, such structures (chiefly the sclerotia) continue to be viable, even for long periods, when seeds are stored.

One of the most effective ways to control the causal agent of white mold disease is the use of seeds with high physiological and health qualities, i.e., free of the resistance structures of pathogen (sclerotia) mixed with the seeds and/or the fungus mycelia sheltered within tegument as well as in the embryonic tissues; thus avoiding its dissemination or its introduction in non-infected areas. Within this context Parisi et al. (2006) point out that the use of seeds with good physiological and health qualities, and that are within the standards of the tolerance established for major crops and diseases, are among the most effective modes to reduce the spread of pathogens; besides contributing on reduction in the use of seeds noncertified that in the case of common beans is quite large in the country. In the last years, the tolerance standards proposed in Brazil for fungus $S$. sclerotiorum establish a zero (0) value to the different classes for common bean seed certification, i. e., by not allowing the presence of the pathogen together with seeds, either in form of contamination through sclerotia and/or the concomitant infection by the fungal mycelia within those seeds (Oliveira, 2005).

Nevertheless, there are only a few reports in the literature on the importance of presence of fungal mycelia in the seeds of different host species in the dissemination of this causal agent of the white mold disease, especially for the common bean seeds. Besides, severity of disease in field not always is correlated to the percentage of seeds infected by the pathogen, once even plants with an apparently small infection by the fungus may produce a large number of heavily infected seeds (Lima et al., 1984). Therefore, considering the importance of high-capacity spread of fungus S. sclerotiorum, it must be admitted that there are still need of more detailed studies on the correlation between the numbers of seeds colonized by this fungus as well as on its spread to growing areas of common beans still not infested by the disease.

In face of the foregoing, this study was performed aiming at assessing the effect of the infection of common beans seeds by the mycelia of fungus $S$. sclerotiorum in the performance as well as in the health quality of the common bean seeds when they are sown under controlled environmental conditions and favorable to the fast development of the white mold disease.

\section{Material ad Methods}

\section{Selection and multiplication of the fungus strains}

The study was carried out in the Seed Testing Laboratory of Department of Phytopathology, of Federal University of Lavras $($ UFLA $=$ Universidade Federal de Lavras), located in municipality of Lavras, State of Minas Gerais, South East Brazil. To this study were used two different strains of the $S$. sclerotiorum fungus registered as CMLAPS O2 (strain S1) and CMLAPS 401(strains S2), both obtained from the Fungi Culture Collection of the DPF-UFLA. Initially, both strains were multiplied into Petri dishes with in diameter, containing of Potato Dextrose Agar medium (PDA), which were incubated into a BOD type chamber, at $20^{\circ} \mathrm{C}$, during five days, with a photoperiod of 12/12 h (L/D). Soon after the first transfer, the original fungal cultures were preserved by the method of Castellani (Figueiredo, 1967).

\section{Procedures used for inoculating the seeds}

Seeds of two common bean cultivars, cv. Pérola and cv. Ouro Negro, produced in the crop season of 2010/2011, were subjected to asepsis with a sodium hypochlorite solution at $1 \%$, during $30 \mathrm{sec}$, and immediately rinsed in sterile distilled water. After such procedure, the seeds were inoculated by using a methodology already described in the literature (Costa et al., 2003; Machado et al., 2001).

For the inoculation of these seeds were used Petri dishes, into which was poured the PDA medium with the water 
potential adjusted to $-1.0 \mathrm{MPa}$, which was modified with mannitol $\left[\mathrm{C}_{6} \mathrm{H}_{6}(\mathrm{OH})_{6}\right]$ and computed using the software SPPM (Michel and Radcliffe, 1995). On this culture medium were put small discs of mycelia of the fungus cut from the edges of the zone of growth of the fungus mycelium developed on the mother plate, with aid of a cork borer previously sterilized. After the inoculation, these plates were also kept in an incubation chamber, at $20^{\circ} \mathrm{C}$, and with a photoperiod of $12 / 12 \mathrm{~h}$, for five days.

After the fungus growth, until covering the whole surface of substrate, the seeds that had been superficially disinfected with sodium hypochlorite during $1 \mathrm{~min}$., were evenly distributed in a single layer upon the fungus colony. The plates containing the fungus + seeds were then placed into an incubation chamber, at $20^{\circ} \mathrm{C}$, during 36, 72, and 96 $\mathrm{h}$, under a photoperiod of $12 / 12 \mathrm{~h}$. These incubation periods correspond to potential of initial inoculum P1, P2, and P3, respectively. Control treatment consisted in the distribution of the same number of seeds into Petri dishes, containing the non-inoculated culture medium and prepared as previously described, for each incubation period and each replication.

After each contact period between the seeds and culture medium, these seeds were removed from the Petri dishes and subjected to drying during $48 \mathrm{~h}$, into a forced air circulation oven, until reaching $12 \%$ moisture content.

Physiological and health quality assessment of seeds infected by the fungus $S$. sclerotiorum with different initial inoculum levels

For this experiment, several different tests were applied to assess physiological and health quality of the seeds, as following described:

To assess health quality of the seeds inoculated with the three different levels of initial inoculum potential (P1, P2, and P3) or the non-inoculated seeds (control), it was used the semi-selective culture medium Agar-Bromophenol Blue, also known as NEON; however, with the modifications described by Napoleão et al. (2006). To this, 200 inoculated seeds with $S$. sclerotiorum, as well as non-inoculated seeds were placed into Petri dishes containing NEON and taken at the incubation chamber, at $20^{\circ} \mathrm{C}$ and photoperiod of $12 / 12 \mathrm{~h}$. From the third day incubation, the 200 inoculated seeds, and well as the 200 non-inoculated seeds were examined searching for formation of a yellow-reddish halo around each seed; which is an indicative of the fungus S. sclerotiorum presence in that seed.

To assess germination of the seeds it was used the test carried out through the method by which subsamples of 50 seeds each, per each treatment, are put to germinate into rolls of germination paper (Germitest ${ }^{\circledR}$ ) moistened with distilled water (Brasil, 2009b). Therefore, in this study were also used samples of 200 seeds for each treatment (control, P1, P2, and P3), which were then split in four subsamples of 50 seeds each, placed upon two sheets of Germitest ${ }^{\circledR}$ paper, covered with another sheet of the same paper, made into rolls and then kept in a germinator under constant temperature of $25 \pm 2{ }^{\circ} \mathrm{C}$. Assessments were performed by counting the number of normal seedlings emerged at day fourth and at day ninth after seeding, according to recommendations of the Rules for Seed Testing (Brasil, 2009a).

To assess germination speed index (GSI), initial stand (IS), final stand (FS), and dry mass of aerial parts and roots, 200 inoculated seeds, as well as 200 non-inoculated seeds of each common bean cultivar were sown in polyethylene trays, containing a mixture of fine sand and soil, at 1:1 ratio. The experiment was carried out into growth chamber and the emergence speed of the seedling was determined by counting of normal seedling emerged. Only the seedlings presenting the cotyledons above the soil line were considered emerged; and the total number of emerged seedlings was obtained by consecutive assessments performed at each two days interval, until stabilization of germination; what occurred 14 days after sowing. The GSI was computed according to equation described by Maguire (1962). The values for the IS and FS were recorded at 10 and 25 days after sowing, respectively, and the absolute value recorded at these two periods was converted in percentage.

Values for dry mass (aerial parts and roots) were obtained 30 days after sowing by weighing all seedlings emerged in each replication. To assess the dry mass, the seedlings were cut at $2 \mathrm{~cm}$ above substrate line and then subjected to the drying process in a forced air circulation oven, at $50{ }^{\circ} \mathrm{C}$ temperature, until reaching constant weight. After $96 \mathrm{~h}$, the so dried material was weighed in a semi-analytical balance, with $0,001 \mathrm{~g}$ precision. Results were expressed in grams.

For all experiments was utilized the completely randomized experimental design with the treatments arranged in a factorial scheme $3 \times 2 \times 2$ ( 3 periods of exposition to initial inoculum potentials $\mathrm{x} 2$ common bean cultivars $\mathrm{x} 2$ strains of fungus), with four replications to each treatment. After verifying additivity of the model, as well as independence of standard deviation, data were subjected to ANOVA. The treatment means were compared by Tukey test at $5 \%$ probability $(\mathrm{p} \leq 0.05)$.

\section{Results and Discussion}

Within this study, it was found that the effect of infection of the common beans seeds by the fungus $S$. sclerotiorum was very high, as much for cv. Pérola as for cv. Ouro Negro, causing germination reduction on percentage of the seeds 
assessed after the inoculation, which was progressive with the increase on the contact period of the seeds with the two fungus strains as compared to initial germination of the seeds of the two cultivars assessed (Table 1).

Table 1. Percentage of initial germination (IG) of seeds of two common bean cultivars in relation to germination of seeds of these cultivars after artificial inoculation with two strains of the fungus S. sclerotiorum (S1 and S2) in three different levels of initial inoculum potentials (P1, P2, and P3) and germination percentage of non-inoculated seeds (WF).

\begin{tabular}{|c|c|c|c|c|c|c|}
\hline \multirow{4}{*}{$\begin{array}{l}\text { Inoculum } \\
\text { potential }\end{array}$} & \multicolumn{6}{|c|}{ Germination (\%) } \\
\hline & \multicolumn{3}{|c|}{ Cv. Pérola } & \multicolumn{3}{|c|}{ Cv. Ouro Negro } \\
\hline & \multicolumn{3}{|c|}{ IG $99.5 \%$} & \multicolumn{3}{|c|}{ IG $99.0 \%$} \\
\hline & $\mathrm{S} 1 * *$ & $\mathrm{~S} 2 * *$ & $\mathrm{WF}^{* *}$ & S1 & S2 & WF \\
\hline $\mathrm{P} 1 * * *$ & $71.5 \mathrm{Aa}^{*}$ & $64.0 \mathrm{Aa}^{*}$ & $97.5 \mathrm{Ab}^{*}$ & $59.5 \mathrm{Aa}^{*}$ & $75.5 \mathrm{Ab}^{*}$ & $98.0 \mathrm{Ac}^{*}$ \\
\hline $\mathrm{P} 2$ & $39.0 \mathrm{Ba}$ & $40.5 \mathrm{Ba}$ & $84.0 \mathrm{Bb}$ & $46.0 \mathrm{Ba}$ & $38.5 \mathrm{Ba}$ & $97.5 \mathrm{Ab}$ \\
\hline P3 & $22.5 \mathrm{Ca}$ & $35.5 \mathrm{Bb}$ & $65.5 \mathrm{Cc}$ & $9.50 \mathrm{Ca}$ & $21.0 \mathrm{Ca}$ & $90.5 \mathrm{Ab}$ \\
\hline \multicolumn{2}{|c|}{ CV (\%) } & & & 11.60 & & \\
\hline
\end{tabular}

*Means followed by the same uppercase letter in the columns and lowercase in lines are not statistically different between each other by the Tukey test $(\mathrm{p} \leq 0.05) . * * \mathrm{~S} 1=$ strain CMLAPS $02 ; \mathrm{S} 2=$ strain CMLAPS 401; WF = without the fungus ***P1, P2, P3 = initial inoculum potential after the contact of the seeds with colonies of fungus grown in Petri dishes on NEON culture medium during 36, 72, and $96 \mathrm{~h}$.

As it can be seen from data presented on that table, in the highest inoculum potential assessed (P3) there was some statistically significant differences between the two cultivars for the two strains of the fungus. The fungus $S$. sclerotiorum may induce intense reductions on the stand of common bean plants in the field, placing it beside other pathogens that are able to cause similar effect in other species of cultivated plants.

In relation to effect of both strains of S. sclerotiorum used in this study, it was observed that the strain S1, in the highest inoculum potential (P3), was the most aggressive to the seeds of both the cultivars assessed (Table 1). It can also be observed that there were statistically significant differences between the percentages of germination of seeds inoculated with both strains, when the two other inoculum potentials (P1 and P2) were used, which demonstrates the aggressiveness of the pathogen.

On considering the fact that $S$. sclerotiorum is a soil-born microorganism, it is worth emphasizing that use of seeds infected by this pathogen can be one of the most common modes of introducing the white mold disease agent in areas still non-infected and therefore determining its quarantine to cultivation of common beans for long periods; thus making them viable only for cultivation of some non-host species. However, the number of these species is limited, once the fungus S. sclerotiorum is considered a pathogen extremely polyphagous and able to cause damages on more than 400 different plant species within more than 250 genera.

Through information achieved in this study, it becomes clear that effect of fungus $S$. sclerotiorum in the seed tissues of common beans, when these seeds are inoculated with different inoculum levels, induces reduction on the germination percentage in a gradual form and inversely correlated to the increase of the inoculum levels. This pattern of action on germination of the seeds was similar for both strains of the fungus as well as for both cultivars assessed.

In the same research line, Machado et al. (2001), by using soybean seeds as hosts, have found that the fungus $S$. sclerotiorum in seeds of this species was highly detrimental to seed germination and to seedling development, as revealed by the test of germination and the total length and the dry weight of the assessed seedlings.

It is worth emphasizing that in the inoculation method used in this study the seeds were kept in contact with the developing fungus colonies during variable time periods and, as control, were used common beans seeds kept in contact with substrate containing only the hydric restrictor and without the fungus presence, during the same time periods. Thus, it was found that contact of seeds with the substrate containing mannitol is likewise a reduction factor for germination capacity of the common beans seeds and that such factor should be considered in the germination test, as indicated by the data presented on Table 1 .

As determined by the germination test, conducted with seeds that had been inoculated with the two isolates of fungus S. sclerotiorum (IS1 and IS2) grown in culture medium AgarBromophenol Blue (a semi-selective method for this fungus) with different potentials of initial inoculum (P1, P2, P3), the incidence of the fungus in the common bean seeds, on the mean, was similar to the two cultivars assessed (Table 2). It is worth noticing that the incidence values of fungus $S$. sclerotiorum are variable depending on the initial inoculum potential applied to the seeds. Despite the fact that by methodology used herein all seeds have been subjected to the 
action of the fungus, results have shown that not all seeds were infected by the pathogen. Therefore, this event proves the information contained in literature according to which there is heterogeneity on variation of the quality of the seeds originating from the same lot (Illipronti et al., 1997).

The common bean seeds used in this study were fully exempted of mycelium and/or sclerotia of fungus $S$. sclerotiorum before inoculation with the different levels of initial inoculum. However, comparing means for percentage of incidence of the two strains of the pathogen in the seed inoculated with the three different levels of initial inoculum, it is possible to verify that actually there was statistically significant differences only to the lower inoculum potential (P1) for the strain S1 (Table 2). Furthermore, it can also be seen that the percentage incidence of the fungus in the seeds inoculated with higher initial inoculum potentials (P2 and P3) was greater for both inoculated strains. This information emphasizes the risk of using common beans seeds infected with the fungus S. sclerotiorum in areas where environmental conditions are favorable for the development of white mold disease, as it has been already stressed in previous studies for this as well as for other pathosystems of agricultural importance (Novembre, 2001, Machado et al., 2001).

Table 2. Incidence (\%) of the fungus S. sclerotiorum in seeds of two common bean cultivars depending on the initial inoculum potential (P1, P2 and P3) of two different of the fungus strains (S1 and S2) and incidence (\%) of the fungus in non- inoculated seeds (WF).

\begin{tabular}{cccc}
\hline \multirow{2}{*}{ Fungal strain } & \multicolumn{3}{c}{ Incidence (\%) } \\
\cline { 2 - 4 } & \multicolumn{3}{c}{ Inoculum potential*** } \\
\cline { 2 - 4 } & $\mathrm{P} 1$ & $\mathrm{P} 2$ & $\mathrm{P} 3$ \\
\hline $\mathrm{S} 1 * *$ & $67.75 \mathrm{Ca}^{*}$ & $94.25 \mathrm{Bb}^{*}$ & $99.00 \mathrm{Bb}^{*}$ \\
$\mathrm{~S} 2$ & $81.25 \mathrm{Ba}$ & $98.75 \mathrm{Bb}$ & $99.75 \mathrm{Bb}$ \\
$\mathrm{WF}$ & $0.00 \mathrm{Aa}$ & $0.00 \mathrm{Aa}$ & $0.00 \mathrm{Aa}$ \\
\hline $\mathrm{CV}(\%)$ & \multicolumn{3}{c}{9.18} \\
\hline
\end{tabular}

*Means followed by the same uppercase letter in the columns and lowercase in lines are not statistically different between each other by the Tukey test $(\mathrm{p} \leq 0.05) . * * \mathrm{~S} 1=$ strain CMLAPS $02 ; \mathrm{S} 2=$ strain CMLAPS 401; WF $=$ without the fungus $* * * \mathrm{P} 1, \mathrm{P} 2, \mathrm{P} 3=$ initial inoculum potential after the contact of the seeds with colonies of fungus grown in Petri dishes on NEON culture medium during 36,72 , and $96 \mathrm{~h}$.

From the values obtained for ESI, it can be observed that the fungus $S$. sclerotiorum has negatively affected in a statistically significant manner the vigor of seeds inoculated with both the isolates, as compared to the non-inoculated seeds (Table 3). By analyzing results obtained for the two cultivars, it can be noticed that there was a consistent superiority of the value of ESI for the cv. Ouro Negro, in relation to cv. Pérola, for both the strains assessed. This value was also higher when the seeds were not inoculated with the fungus. However, there was a reduction in the values of ESI for both cultivars, when seeds were exposed to contact with the two strains of the fungus as compared to the seeds free of the pathogen. Nevertheless, this value did not change when the seeds were not inoculated (Table 4).

Table 3. Values of emergence speed index (ESI) obtained for the seeds of two common bean cultivars after being inoculated with two different strains of the fungus $S$. sclerotiorum (IS1 and IS2), as well as for the seeds non-inoculated with the fungus (WF).

\begin{tabular}{cccc}
\hline \multirow{2}{*}{ Cultivar } & \multicolumn{3}{c}{ ESI/fungal strain** } \\
\cline { 2 - 4 } & $\mathrm{S} 1$ & $\mathrm{~S} 2$ & $\mathrm{WF}$ \\
\hline Pérola & $1.08 \mathrm{Aa}^{*}$ & $1.50 \mathrm{Aa}^{*}$ & $3.08 \mathrm{Ab}^{*}$ \\
Ouro Negro & $2.71 \mathrm{Ba}$ & $2.35 \mathrm{Ba}$ & $3.72 \mathrm{Bb}$ \\
\hline CV $(\%)$ & & 19.05 \\
\hline
\end{tabular}

* Means followed by the same uppercase letter in the columns and lowercase in lines are not statistically different between each other by the Tukey test $(\mathrm{p} \leq 0.05) . * * \mathrm{~S} 1=$ strain CMLAPS $02 ; \mathrm{S} 2=$ strain CMLAPS $401 ; \mathrm{WF}=$ without the fungus.

Table 4. Mean values obtained for the emergence speed index (ESI) for seeds of two common bean cultivars after being inoculated with two different isolates of the fungus $S$. sclerotiorum (S1 and S2) with different initial inoculum potentials (P1, P2 and P3) and mean values of ESI obtained for the non-inoculated seeds (WF).

\begin{tabular}{cccc}
\hline \multirow{2}{*}{$\begin{array}{c}\text { Fungal } \\
\text { strain }\end{array}$} & $\mathrm{P} 1 * * *$ & $\mathrm{P} 2 * * *$ & $\mathrm{P} 3 * * *$ \\
\cline { 2 - 4 } $\mathrm{S} 1 * *$ & $2.94 \mathrm{Aa}^{*}$ & $1.58 \mathrm{Ab}^{*}$ & $1.17 \mathrm{Ab}^{*}$ \\
$\mathrm{~S} 2$ & $3.79 \mathrm{Ba}$ & $1.15 \mathrm{Ab}$ & $0.84 \mathrm{Ab}$ \\
$\mathrm{WF}$ & $3.53 \mathrm{Ba}$ & $3.38 \mathrm{Ba}$ & $3.30 \mathrm{Ba}$ \\
\hline $\mathrm{CV}(\%)$ & & 19.05 & \\
\hline
\end{tabular}

* Means followed by the same uppercase letter in the columns and lowercase in lines are not statistically different between each other by the Tukey test $(\mathrm{p} \leq 0.05) . * * \mathrm{~S} 1=$ strain CMLAPS 02; S2 $=$ strain CMLAPS $401 ; \mathrm{WF}=$ without the fungus $* * * \mathrm{P} 1, \mathrm{P} 2, \mathrm{P} 3=$ initial inoculum potential after the contact of the seeds with colonies of fungus grown in Petri dishes on NEON culture medium during 36, 72, and $96 \mathrm{~h}$

On comparing the means obtained for the ESI of the seeds inoculated with the two strains of the fungus, it can be observed that there was statistically significant difference between the strains S1 and S2 only on the lower initial inoculum potential assessed (P1). It can also be observed that the ESI values have decreased with the increase on the initial inoculum potential (Table 4). It can also be observed that there was reduction on the IVE values with the increase of the potential of the initial inoculum. By analysis of results obtained for each 
strain within the different initial inoculum potentials, it can be observed that there was statistically significant difference for both strains only for the lowest potential of initial inoculum (P1), which has presented the highest IVE, with subsequent decline when time of contact with the pathogen was increased.

The effect of inoculation of the two strains of fungus $S$.

Table 5. Mean percentage values obtained for the initial stand of seedlings of two common bean cultivars obtained from the seeds inoculated with two strains of the fungus $S$. sclerotiorum (S1 and S2); as well as for the non-inoculated seed (WF).

\begin{tabular}{|c|c|c|c|}
\hline \multirow{3}{*}{ Cultivar } & \multicolumn{3}{|c|}{ Initial stand (\%) } \\
\hline & \multicolumn{3}{|c|}{ Fungal strain** } \\
\hline & S1 & S2 & WF \\
\hline Pérola & $31.00 \mathrm{Aa}^{*}$ & $36.50 \mathrm{Aa}^{*}$ & $72.16 \mathrm{Ab}^{*}$ \\
\hline Ouro Negro & $70.50 \mathrm{Ba}$ & $62.33 \mathrm{Ba}$ & $91.83 \mathrm{Bb}$ \\
\hline CV (\%) & \multicolumn{3}{|c|}{14.81} \\
\hline
\end{tabular}

*Means followed by the same uppercase letter in the columns and lowercase in lines are not statistically different between each other by the Tukey test $(\mathrm{p} \leq 0.05) .{ }^{* *} \mathrm{~S} 1=$ strain CMLAPS 02; S2 = strain CMLAPS 401; WF = without the fungus.

Table 6. Mean percentage values of initial stand of seedlings of two common beans cultivars, originating from seeds inoculated with two strains of the fungus $S$. sclerotiorum (S1 and S2) with three different initial inoculum potentials (P1, P2 and P3), as well as for the non-inoculated seed (WF).

\begin{tabular}{cccc}
\hline \multirow{2}{*}{$\begin{array}{c}\text { Cultivar/fungal } \\
\text { strain** }\end{array}$} & \multicolumn{3}{c}{ Initial stand (\%) } \\
\cline { 2 - 4 } & $\mathrm{3} 1^{* * *}$ & $\mathrm{P} 2^{* * *}$ & $\mathrm{P} 3^{* * *}$ \\
\cline { 2 - 4 } Pérola & $70.50 \mathrm{Ab}^{*}$ & $39.00 \mathrm{Aa}^{*}$ & $30.17 \mathrm{Aa}^{*}$ \\
Ouro Negro & $91.00 \mathrm{Ba}$ & $70.00 \mathrm{Bb}$ & $63.67 \mathrm{Bb}$ \\
\hline $\mathrm{CV}(\%)$ & 14.81 \\
\hline Isolates & $\mathrm{P} 1^{* * *}$ & $\mathrm{P} 2^{* * *}$ & $\mathrm{P} 3^{* * *}$ \\
\hline $\mathrm{S} 1$ & $75.25 \mathrm{Ab}$ & $42.50 \mathrm{Aa}$ & $34.50 \mathrm{Aa}$ \\
$\mathrm{S} 2$ & $82.75 \mathrm{Ac}$ & $38.50 \mathrm{Ab}$ & $27.00 \mathrm{Aa}$ \\
$\mathrm{WF}$ & $84.25 \mathrm{Aa}$ & $82.50 \mathrm{Ba}$ & $79.25 \mathrm{Ba}$ \\
\hline $\mathrm{CV}(\%)$ & \multicolumn{3}{|}{14.81} \\
\hline
\end{tabular}

*Means followed by the same uppercase letter in the columns and lowercase in lines are not statistically different between each other by the Tukey test $(\mathrm{p} \leq 0.05) . * * \mathrm{~S} 1=$ strain CMLAPS 02; S2 $=$ strain CMLAPS 401; WF $=$ without the fungus $* * * \mathrm{P} 1, \mathrm{P} 2, \mathrm{P} 3=$ initial inoculum potential after the contact of the seeds with colonies of fungus grown in Petri dishes on NEON culture medium during 36, 72, and $96 \mathrm{~h}$.

By comparing the mean values of the percentage of initial stand of the seedlings obtained from the seeds of both the sclerotiorum in the seeds of both cultivars was variable when the experiment was conducted in mixed substrate of sand and soil and under favorable environmental conditions for the development of white mold disease, allowing detecting differences statistically significant as much between the two cultivars as among the different levels of initial inoculum potential (Tables 5, 6, 7 and 8).

Table 7. Mean percentage values obtained for the final stand for seedlings of two common beans cultivars, originating from seeds inoculated with two strains of the fungus S. sclerotiorum (S1 and S2), as well as for seedlings originating from seeds non-inoculated with the fungus (WF).

\begin{tabular}{cccc}
\hline \multirow{2}{*}{ Cultivar } & \multicolumn{3}{c}{ Final stand (\%) } \\
\cline { 2 - 4 } & $\mathrm{S} 1$ & $\mathrm{~S} 2$ & $\mathrm{WF}$ \\
\cline { 2 - 4 } & $24.33 \mathrm{Aa}^{*}$ & $32.33 \mathrm{Aa}^{*}$ & $78.00 \mathrm{Ab}^{*}$ \\
Pérola & $55.00 \mathrm{Ba}$ & $51.0 \mathrm{Ba}$ & $94.66 \mathrm{Bb}$ \\
\hline Ouro Negro & \multicolumn{3}{c}{17.1} \\
\hline CV $(\%)$ & & \multicolumn{3}{c}{} \\
\hline
\end{tabular}

* Means followed by the same uppercase letter in the columns and lowercase in lines are not statistically different between each other by the Tukey test $(\mathrm{p} \leq 0.05){ }^{* *} \mathrm{~S} 1=$ strain CMLAPS 02; S2 = strain CMLAPS 401; WF = without the fungus.

Table 8. Mean percentage values obtained for the final stand of common beans seedlings originating from seeds inoculated with three different inoculum initial potentials (P1, P2 and P3) of two strains of the fungus S. sclerotiorum (S1 and S2); as well as of seedlings originating from seeds non-inoculated with the fungus (WF).

\begin{tabular}{cccc}
\hline \multirow{2}{*}{ Fungal strain } & \multicolumn{3}{c}{ Final stand (\%) } \\
\cline { 2 - 4 } & \multicolumn{3}{c}{ Inoculum potential } \\
\cline { 2 - 4 } & $\mathrm{P} 1 * * *$ & $\mathrm{P} 2 * * *$ & $\mathrm{P} 3 * * *$ \\
\hline $\mathrm{S} 1 * *$ & $63.75 \mathrm{Ab}^{*}$ & $31.50 \mathrm{Aa}^{*}$ & $23.75 \mathrm{Aa}^{*}$ \\
$\mathrm{~S} 2$ & $84.50 \mathrm{Bb}$ & $24.50 \mathrm{Aa}$ & $16.00 \mathrm{Aa}$ \\
$\mathrm{WF}$ & $89.50 \mathrm{Ba}$ & $85.75 \mathrm{Ba}$ & $83.75 \mathrm{Ba}$ \\
\hline $\mathrm{C}(\%)$ & \multicolumn{3}{|c}{17.41} \\
\hline
\end{tabular}

*Means followed by the same uppercase letter in the columns and lowercase in lines are not statistically different between each other by the Tukey test $(\mathrm{p} \leq 0.05) . * * \mathrm{~S} 1=$ strain CMLAPS 02; S2 = strain CMLAPS 401; WF = without the fungus $* * * \mathrm{P} 1, \mathrm{P} 2, \mathrm{P} 3=$ initial inoculum potential after the contact of the seeds with colonies of fungus grown in Petri dishes on NEON culture medium during 36,72 , and $96 \mathrm{~h}$.

common beans cultivars inoculated with both strains of the fungus, as well as of non-inoculated seeds, it can be observed 
that germination of the seeds of cv. Pérola were more severely affected than the seeds of cv. Ouro Negro (Table 5).

There was a gradual reduction of the initial stand of the seedlings with increase of initial inoculum potential applied to seeds of the two cultivars as much for the strain S1, as for strain $\mathrm{S} 2$, with statistically significant differences between potentials of initial inoculum P1 and P3 (Table 6). However, as expected, this reduction was not observed for the initial stand of seedlings originating from non-inoculated seeds (WF).

For the mean values obtained to the final stand of seedlings assessed at 28 days after sowing, it was observed that there were statistically significant differences between the means obtained only for the seeds inoculated with both the fungus strains (S1 and S2) and also for the non-inoculated seeds (WF), for both the cultivars assessed (Table 7). However, the final stand for the seedlings of the cultivar Ouro Negro was higher in all treatments applied.

The value of the means obtained for the final stand of the seedlings in the control treatment, i.e., without inoculation of the seeds with the fungus (WF), has remained statistically unchanged, but with values statistically higher than the values obtained for the final stand of seedlings originating from seeds subjected to the two initial inoculum potentials assessed; except for the seeds inoculated with strain S2, in the lowest potential of initial inoculum (P1), which was statistically equal.

By what has been discussed up to this point can be emphasized that in this study it was observed many induced reductions by fungus $S$, sclerotiorum in the values for germination and seed vigor of both the cultivars of common beans assessed, when these seeds were inoculated with the mycelium from the two different strains of the fungus, what was also reflected in the values obtained for the final stand of seedlings.

In relation to effects of inoculation of the seeds with fungus $S$. sclerotiorum on dry mass production of aerial parts of the seedlings emerged, it was found that there was no statistically significant variation between the means obtained for the seedlings of both common beans cultivars, when these seedlings were originating from seeds inoculated with the two strains of the fungus or originating from non-inoculated seeds (Table 9). By the means obtained for the control treatment (WF) it was also observed that cv. Pérola has produced higher amount of dry mass than cv. Ouro Negro. A similar result was found by Andrade et al. (2009) in a study performed with common beans seedlings; however comparing the cv. BRS MG Talismã with the cv. Ouro Negro.

Through means obtained for dry mass of roots of the seedlings of the two cultivars assessed, originating from the seeds inoculated with both the strains of the fungus, or originating from non-inoculated seeds, it can be noticed that there was reduction in dry mass of the seedlings, when the initial inoculum potential applied to seeds has been increased (Table 10).

Table 9. Mean values obtained for dry mass of aerial parts of seedlings of two common beans cultivars, originating from seeds inoculated with two different isolates of the fungus S. sclerotiorum (S1 and S2), as well as from seeds non-inoculated with the fungus (WF).

\begin{tabular}{|c|c|c|c|}
\hline \multirow{3}{*}{ Cultivar } & \multicolumn{3}{|c|}{ Dry mass (g) } \\
\hline & \multicolumn{3}{|c|}{ Fungal strain** } \\
\hline & S1 & S2 & WF \\
\hline Pérola & $10.33 \mathrm{Aa}^{*}$ & $9.63 \mathrm{Aa}^{*}$ & $15.90 \mathrm{Ab}^{*}$ \\
\hline Ouro Negro & $9.39 \mathrm{Aa}$ & $10.70 \mathrm{Aa}$ & $24.32 \mathrm{Bb}$ \\
\hline CV (\%) & \multicolumn{3}{|c|}{25.16} \\
\hline
\end{tabular}

*Means followed by the same uppercase letter in the columns and lowercase in lines are not statistically different between each other by the Tukey test $(\mathrm{p} \leq 0.05) . * * \mathrm{~S} 1=$ strain CMLAPS 02; S2 = strain CMLAPS 401; WF = without the fungus.

Table 10. Means obtained for dry mass of roots of seedlings of two common beans cultivars, originating from seeds inoculated with two different strains of the fungus S. sclerotiorum (S1 and S2), at different levels of initial inoculum (P1 and P2), as well as seeds non-inoculated with the fungus (WF).

\begin{tabular}{ccccccc}
\hline Inoculum & \multicolumn{3}{c}{ Dry mass $(\mathrm{g})$} \\
\hline \multicolumn{1}{c}{ potential } & \multicolumn{3}{c}{ Cv. Pérola } & \multicolumn{3}{c}{ Cv. Ouro Negro } \\
\hline & $\mathrm{S} 1$ & $\mathrm{~S} 2$ & $\mathrm{WF}$ & $\mathrm{S} 1$ & \multicolumn{2}{c}{ Fungal strain** } \\
\hline $\mathrm{P} 1$ *** & $8.39 \mathrm{Aa}^{*}$ & $7.61 \mathrm{Aa}^{*}$ & $11.21 \mathrm{Ab}^{*}$ & $6.99 \mathrm{Aa}^{*}$ & $8.99 \mathrm{Aa}^{*}$ & $19.17 \mathrm{Ac}^{*}$ \\
$\mathrm{P} 2$ & $5.41 \mathrm{Ba}$ & $5.21 \mathrm{Ba}$ & $9.41 \mathrm{Bb}$ & $5.97 \mathrm{Aa}$ & $5.97 \mathrm{Ba}$ & $14.5 \mathrm{Bb}$ \\
$\mathrm{P} 3$ & $4.76 \mathrm{Ba}$ & $4.52 \mathrm{Ba}$ & $8.00 \mathrm{Bb}$ & $4.02 \mathrm{Ba}$ & $4.28 \mathrm{Ba}$ & $9.6 \mathrm{Cb}$ \\
\hline & $\mathrm{CV}(\%)$ & & & 12.84 & &
\end{tabular}

*Means followed by the same uppercase letter in the columns and lowercase in lines are not statistically different between each other by the Tukey test $(\mathrm{p} \leq 0.05) . * * \mathrm{~S} 1=$ strain CMLAPS 02; S2 = strain CMLAPS 401; WF = without the fungus ***P1, P2, P3 = initial inoculum potential after the contact of the seeds with colonies of fungus grown in Petri dishes on NEON culture medium during 36, 72, and $96 \mathrm{~h}$. 


\section{Conclusions}

The presence of the fungus $S$. sclerotiorum in common bean seeds in the form of mycelium, regardless of the initial inoculum potential, causes progressive and marked reductions of germination and vigor of seeds, besides causing reductions on the initial stand, and of dry mass and total length of the seedlings, when the environmental conditions are favorable to development of the white mold disease;

The deleterious effects of the fungus $S$. sclerotiorum upon the common bean seeds may vary depending on the strain of the pathogen used for inoculation; but is independent on the cultivar from which these seeds were harvested;

The high initial inoculum potential of the fungus $S$. sclerotiorum in common bean seeds may cause progressive damage to the plants in the field due to the rapid spread of the pathogen to new plants; and

The use of bean seeds infected by the fungus $S$. sclerotiorum contributes to reduced productivity of this crop under environmental conditions favorable to development of the white mold disease.

\section{Acknowledgements}

We thank the CNPq and FAPEMIG for the financing support for the development of this research work.

\section{References}

ANDRADE, C.A.B.; SCAPIM, C.A.; BRACCINI, A.L.; MARTORELLI, D.T. Produtividade, crescimento e partição de matéria seca em duas cultivares de feijão. Acta Scientiarum Agronomy, v.31, n.4, p.683-688, 2009. http:// www.scielo.br/pdf/asagr/v31n4/a20v31n4.pdf

BRASIL. Ministério da Agricultura, Pecuária e Abastecimento. Regras para análise de sementes. Ministério da Agricultura, Pecuária e Abastecimento. Secretaria de Defesa Agropecuária. Brasília, DF: MAPA/ ACS Brasília, DF: 2009a. 395p. http://www.scielo.br/scielo.php?script=sci nlinks\&ref $=000057 \&$ pid $=$ S0101-3122201100040000400003\&lng=en

BRASIL. Ministério da Agricultura, Pecuária e Abastecimento. Manual de análise sanitária de sementes. Ministério da Agricultura, Pecuária e Abastecimento. Secretaria de Defesa Agropecuária. Brasília: MAPA/ACS, 2009b. 200p. http://www.agricultura.gov.br/arq_editor/file/3376_manual_de_ analise_sanitaria_de_sementes.pdf

COSTA, M.L.N.; MACHADO, J.C.M.; GUIMARÃES, R.M.; POZZA, E.A.; ORIDE, D. Inoculação de Fusarium oxysporum f.sp. phaseoli em sementes de feijoeiro através de restrição hídrica. Ciência e Agrotecnologia, v.27, n.5, p.1023-1030. 2003. http://www.scielo.br/pdf/cagro/v27n5/a08v27n5.pdf
FIGUEIREDO, M.B. Estudos sobre a aplicação do método de Castellani para conservação de fungos patógenos em plantas. O Biológico, v.33, p.9-13, 1967.

HARVESON, R.M.; STEADMAN, J.R.; URREA, C.A. Integrating planting dates and fungicide applications for managing white mold of dry beans in western Nebraska. Plant Health Progress, 2010. http://www. plantmanagementnetwork.org/pub/php/research/2010/whitemold/

ILLIPRONTI JÚNIOR, R.A.; LANGERAK, C.J.; LOMMEN, W.J.M Variation in and relationships between physical and physiological seed attributes within a soybean seed lot. Seed Science Technology, v.25, n.2, p.21531, 1997. http://www.refdoc.fr/detailnotice?cpsidt=2045874\&traduire=fr

LIMA, E.F.; CARVALHO, J.M.F.V.; CARVALHO, L.P.; COSTA, J.N. Transporte e transmissibilidade de Colletotrichum gossypii var cephalosporioides, através das sementes de algodão. Fitopatologia Brasileira, v.10, n.1, p.105-115. 1984

MACHADO, J.C. Patologia de sementes: fundamentos e aplicações. Lavras: ESAL/FAEPE, 1988. 107p

MACHADO, J.C.; OLIVEIRA, J.A.; VIEIRA, M.G.G.C.; ALVES, M.C. Inoculação artificial de sementes de soja por fungos utilizando solução de manitol. Revista Brasileira de Sementes, v.23, n.2, p.95-101. 2001. http:// www.abrates.org.br/revista/artigos/2001/v23n2/artigo13.pdf

MAGUIRE, J.D. Speed of germination-aid in selection and evaluation for seedling emergence and vigour. Crop Science, v.2, n.2, p.176-177. 1962. https://www.soils.org/publications/cs/abstracts/2/2/cs0020020176

MERTZ, L.M.; HENNING, F.A.; MAIA, M.S.; MENEGHELLO, G.E.; HENRIQUES, A.; MADAIL, R. Qualidade fisiológica e sanitária de sementes de feijão-miúdo beneficiados em mesa gravitacional. Revista Brasileira de Sementes, v.29, n.3, 2007. http://www.scielo.br/scielo.php?script=sci arttext\&pid=s0101-31222007000300001

MICHEL, B.E.; RADCLIFFE, D. A computer program relating solute potential to solution composition for five solutes. Agronomy Journal, v.87, n.1, p.131-136, 1995. http://cat.inist.fr/?amodele=affichen $\&$ cpsidt=3448030

NAPOLEAO, R.; NASSER, L.; LOPES, C.; FILHO, A.C. Neon-S, novo meio para detecção de Sclerotinia sclerotiorum em sementes. Summa Phytopathologica, v.32, n.2, p.180-182, 2006. http://www.scielo.br/scielo. php?script=sci_arttext\&pid=s0100-54052006000200014

NOVEMBRE, A.D.L.C. Avaliação da qualidade de sementes. Seed News, v.5, n.3 2001. http://www.seednews.inf.br/ html/site/content/edicoes anteriores/edicoes antigas.php?codigo $=53 \&$ janela $=$ reportagemcapa. Accessed on: Apr. $04^{\text {th }} 2012$

OLIVEIRA, S.H.F. Manejo do mofo branco. DBO Agrotecnologia, v.2, n.4, p.8-13, 2005. http://www.jcofertilizantes.com.br/pesquisa/pesquisa2manejo-do-mofo-branco.pdf

PARISI, J.J.D.; PATRÍCIO, F.R.A.; OLIVEIRA, H.F. Método do rolo de pape toalha modificado para a detecção de Sclerotinia sclerotiorum em sementes de feijão. Summa Phytopathologica, v.32, n.3, p.288-290, 2006. http://www. scielo.br/scielo.php?pid=s0100-54052006000300015\&script=sci_arttex

ZANCAN, W.L.A.; MACHADO, J.C.; SOUSA, B.F.M.; MATOS, C.S.M Crescimento micelial, produção e germinação de escleródios de Sclerotinia sclerotiorum na presença de fungicidas químicos e Trichoderma harzianum. Bioscience Journal, v.28, n.5, p.782-789, 2012. http://www.seer.ufu.br/index. $\mathrm{php} /$ biosciencejournal/article/view/13909 